\title{
Studies on Growth, Yield and Quality of Garlic (Allium sativum L.) as Affected by Herbicides and Weeds
}

\author{
Badri Vishal Patil ${ }^{1}$, I. S. Naruka ${ }^{1}$, R. P. S. Shaktawat ${ }^{*}$ and K. S. Verma ${ }^{1}$ \\ ${ }^{1}$ Dept. of Spices, Medicinal, Aromatic and Plantation Crops ${ }^{2}$ Dept. of Agronomy, KVK, College of Horticulture, \\ Mandsaur, M.P. (458 001), India
}

\section{Article History}

Manuscript No. AR1540a

Received in $21^{\text {st }}$ February, 2016

Received in revised form $25^{\text {th }}$ August, 2016

Accepted in final form $5^{\text {th }}$ October, 2016

\section{Correspondence to}

"E-mail: rpssbkn@yahoo.co.in

\section{Keywords}

Garlic (Allium sativum L.), chemical, weed, control

\begin{abstract}
A field experiment was conducted at the research farm, College of Horticulture, Mandsaur (Madhya Pradesh), India during the rabi 2012-13 to study the effect of different herbicides on weed and performance of garlic (Allium sativum L.). There were ten treatments in the experiment consisted of cultural methods and different herbicides and their doses. The different treatments significantly influenced the growth, yield and quality attributes of garlic. Significant maximum plant height, number of leaves plant ${ }^{-1}$, chlorophyll content in leaves, leaf area plant ${ }^{-1}$, TSS content of bulb (\%), volatile oil content in bulb (\%), neck thickness, number of cloves bulb ${ }^{-1}$, fresh and dry weight of 20 cloves, pollar and equatorial diameter of bulb, fresh and dry weight of bulb and bulb yield were recorded with weed free treatment followed by oxyfluorfen 23.5\% EC@1.01 ha ha $^{-1}$ and oxadiargyl6\% EC @ 1.01 ha $^{-1}$. Similarly minimum days to maturity, weed population $\mathrm{m}^{-2}$ at 60 and 90 DAS and weed dry matter at harvest was recorded with weed free treatment followed by oxyfluorfen 23.5\% EC @ 1.01 ha $^{-1}$ and oxadiargyl 6\% EC @ 1.01 ha $^{-1}$. Among the treatment applied, Oxyfluorfen 23.5\% EC@1.01 ha ${ }^{-1}$, Oxadiargyl6\% EC@1.01 ha ${ }^{-1}$ and weed free treatment gave significantly highest bulb yield by $125.90,124.54$ and $126.63 \mathrm{q} \mathrm{ha}^{-1}$ which were at par with each other.
\end{abstract}

\section{Introduction}

Garlic (Allium sativum L.) is the second most important bulb crop after onion in Alliaceae family. The economic yield is obtained from its underground developed part known as bulb. Its pungent flavour makes it used mainly as a spice, seasoning and flavoring for foodstuff involving both green tops and bulbs. Its medicinal value is also well recognized in the control and treatment of hypertension, worms, germs, bacterial and fungal diseases, diabetes, cancer, ulcer, rheumatism etc. (Kilgori et al., 2007). India ranks second in area and production of garlic in the World. It is cultivated in 242 thousand ha producing 1228 thousand $\mathrm{t}$ with productivity of $5.1 \mathrm{t} \mathrm{ha}^{-1}$. In Madhya Pradesh, it is grown in about 60 thousand ha with total production of 270 thousand MT giving an average production of $4.5 \mathrm{tha}^{-1}$. Madhya Pradesh ranks first in area and second in production after Gujarat (NHB, 2012). The average yield of garlic in India is very low as compared to other leading countries due to many factors. One of the main limiting factor's is weed infestation which compete with garlic for nutrients, soil moisture, space, and light. Considerably reduce the yield, quality and value of the crop through increased production and harvesting costs (Rahman et al., 2012). Garlic is closely planted crop with very small canopy. Weeds compete with crop plants at very early growth stages. The losses caused by weeds have been estimated to be much higher. Generally the yield of crop is reduced by 30 to $60 \%$ due to weeds infestation. Usually farmers do not remove weeds earlier enough to prevent crop from major damages caused by weeds. Keeping all these in mind, an experiment to study on effect of different herbicides on weed and performance of garlic (Allium sativum L.) was conducted.

\section{Materials and Methods}

The field experiment was conducted during rabi season 2012-13 at the Research Farm, College of Horticulture, Mandsaur (Madhya Pradesh), India on light black loamy soil having $\mathrm{pH} 7.2$, EC $0.35 \mathrm{dS} \mathrm{m}^{-1}$, low level of available nitrogen $\left(243.2 \mathrm{~kg} \mathrm{ha}^{-1}\right)$, medium in available phosphorus $(19.75 \mathrm{~kg}$ $\left.\mathrm{ha}^{-1}\right)$ and high in available potassium (448.0 $\left.\mathrm{kg} \mathrm{ha}^{-1}\right)$. The average annual rainfall is $876 \mathrm{~mm}$. The experiment was laid out in Randomized Block Design having three replications. 
There were ten treatments in experiment viz., Control (weedy), Weed free, Pendimethalin 30\% EC @ $2.51 \mathrm{ha}^{-1}$, Pendimethalin 30\% EC@1.5 1 ha ${ }^{-1}$, Oxyfluorfen 23.5\% EC@1.0 1 ha-1, Oxyfluorfen 23.5\% EC @ 0.751 ha $^{-1}$, Oxadiargyl6\% EC @ $1.01 \mathrm{ha}^{-1}$, Oxadiargyl 6\% EC@ $0.751 \mathrm{ha}^{-1}$, Oxadiazon 25\% EC @ $1.01 \mathrm{ha}^{-1}$ and Oxadiazon 25\% EC @ 0.81 ha $^{-1}$. Sowing of cloves of bulbs of G-1 cultivar was done in prepared beds 5-7 $\mathrm{cm}$ deep keeping their growing ends upwards at $15 \times 10 \mathrm{~cm}^{2}$ on $10^{\text {th }}$ November, 2012. After sowing cloves were covered with the thin layer of soil for its proper germination. A basal dose of well rotten farmyard manure @ $10 \mathrm{t} \mathrm{ha}^{-1}$ was incorporated in the soil before one month of sowing. In addition to this, a uniform dose of $150 \mathrm{~kg} \mathrm{~N} \mathrm{ha-1}, 60 \mathrm{~kg} \mathrm{P}_{2} \mathrm{O}_{5} \mathrm{ha}^{-1}, 40 \mathrm{~kg} \mathrm{~K} 2 \mathrm{O}$ $\mathrm{ha}^{-1}$ and $60 \mathrm{~kg}$ Sulphur ha ${ }^{-1}$ was applied for better growth and proper nutrition of garlic. In order to protect the crop from insect thrips, spray of Fipronil is done. Irrigations were given from sowing to harvesting as per schedule. The first irrigation was given just after sowing and irrigation was withheld before 20 days of harvest. Harvesting was done manually by hand digger when the top turn yellowish or brown colour and shown signs of drying up and bend over (neck fall stage). The harvested bulbs with tops were weighed and subjected to other observations. Quality parameters viz., TSS content of bulb (\%) was determinate with the help of hand refractometer, chlorophyll content in leaves at 60 and 90 days after sowing was measured by spad meter instrument (Spad value) and volatile oil content in bulb (\%) was determined by using essential oil distillation assembly (A.O.A.C., 1970). In each plot a quadrate was used for counts of weed and dry matter accumulation of weeds.

\section{Results and Discussion}

\subsection{Effect on growth of garlic}

Application of different weed control measures had significant effect on different growth attributes viz., plant height and number of leaves (Table 1). Among the different treatments tested, weed free treatment recorded significant maximum plant height (66.5 and 68.8) at 90 DAS and at harvest, respectively. Among the herbicides, oxyfluorfen 23.5\% EC @ 1.01 ha $^{-1}$ recorded 53.6, 66.0 and $68.0 \mathrm{~cm}$ plant height at 60,90 DAS

Table 1: Effect of weed control measures on different growth and quality attributes of garlic

\begin{tabular}{|c|c|c|c|c|c|c|c|c|c|c|c|c|}
\hline \multirow[t]{2}{*}{ Treatment } & \multicolumn{4}{|c|}{ Plant height $(\mathrm{cm})$} & \multicolumn{4}{|c|}{ Number of leaves plant $^{-1}$} & \multirow[b]{2}{*}{$\begin{array}{c}\text { Leaf } \\
\text { area } \\
\text { plant }{ }^{-1} \\
\text { at } 120 \\
\text { DAS } \\
\left(\mathrm{cm}^{2}\right)\end{array}$} & \multirow[b]{2}{*}{$\begin{array}{l}\text { Chloro- } \\
\text { phyll } \\
\text { con- } \\
\text { tent in } \\
\text { leaves } \\
\text { (SPAD) }\end{array}$} & \multirow{2}{*}{$\begin{array}{l}\text { TSS } \\
\text { cont- } \\
\text { ent of } \\
\text { bulb } \\
(\%)\end{array}$} & \multirow[b]{2}{*}{$\begin{array}{c}\text { Vola- } \\
\text { tile } \\
\text { oil } \\
\text { content } \\
\text { of bulb } \\
(\%)\end{array}$} \\
\hline & $\begin{array}{c}30 \\
\text { DAS }\end{array}$ & $\begin{array}{c}60 \\
\text { DAS }\end{array}$ & $\begin{array}{c}90 \\
\text { DAS }\end{array}$ & $\begin{array}{c}\text { At } \\
\text { harvest }\end{array}$ & $\begin{array}{c}30 \\
\text { DAS }\end{array}$ & $\begin{array}{c}60 \\
\text { DAS }\end{array}$ & $\begin{array}{c}90 \\
\text { DAS }\end{array}$ & $\begin{array}{c}\text { At } \\
\text { harvest }\end{array}$ & & & & \\
\hline Control & 37.6 & 41.1 & 43.5 & 49.7 & 5.53 & 6.07 & 7.87 & 8.83 & 159.57 & 75.44 & 29.00 & 0.42 \\
\hline Weed free & 36.0 & 53.4 & 66.5 & 68.8 & 5.53 & 8.10 & 10.83 & 12.80 & 202.00 & 117.43 & 35.67 & 0.63 \\
\hline $\begin{array}{l}\text { Pendimethalin } 30 \% \\
\text { EC @ } 2.51 \mathrm{ha}^{-1}\end{array}$ & 37.8 & 46.6 & 54.6 & 60.2 & 5.60 & 6.40 & 9.13 & 10.00 & 171.53 & 88.07 & 30.00 & 0.48 \\
\hline $\begin{array}{l}\text { Pendimethalin } 30 \% \\
\text { EC @ } 1.51 \mathrm{ha}^{-1}\end{array}$ & 39.7 & 45.3 & 54.4 & 60.0 & 5.60 & 6.07 & 8.93 & 9.87 & 179.87 & 80.50 & 29.67 & 0.45 \\
\hline $\begin{array}{l}\text { Oxyfluorfen } 23.5 \% \\
\text { EC @ } 1.01 \mathrm{ha}^{-1}\end{array}$ & 36.3 & 53.6 & 66.0 & 68.0 & 5.40 & 7.93 & 10.77 & 12.67 & 206.33 & 116.75 & 35.33 & 0.62 \\
\hline $\begin{array}{l}\text { Oxyfluorfen } 23.5 \% \\
\text { EC @ } 0.751 \mathrm{ha}^{-1}\end{array}$ & 36.3 & 48.8 & 55.2 & 61.1 & 5.27 & 6.67 & 9.60 & 12.47 & 195.67 & 87.90 & 31.67 & 0.52 \\
\hline $\begin{array}{l}\text { Oxadiargyl 6\% EC } \\
\text { (a) } 1.01 \mathrm{ha}^{-1}\end{array}$ & 36.9 & 52.07 & 63.3 & 65.67 & 5.20 & 7.87 & 10.70 & 12.53 & 198.30 & 116.07 & 32.33 & 0.61 \\
\hline $\begin{array}{l}\text { Oxadiargyl 6\% EC } \\
\text { @ } 0.751 \mathrm{ha}^{-1}\end{array}$ & 35.4 & 52.1 & 55.4 & 62.1 & 5.07 & 6.73 & 9.63 & 12.73 & 196.27 & 105.03 & 33.00 & 0.57 \\
\hline $\begin{array}{l}\text { Oxadiazon 2\% EC } \\
\text { (a) } 1.01 \mathrm{ha}^{-1}\end{array}$ & 36.2 & 49.8 & 56.6 & 62.4 & 5.53 & 6.77 & 9.67 & 11.37 & 186.33 & 101.52 & 32.67 & 0.55 \\
\hline $\begin{array}{l}\text { Oxadiazon } 25 \% \text { EC } \\
\text { (a) } 0.81 \mathrm{ha}^{-1}\end{array}$ & 37.6 & 48.7 & 54.7 & 60.2 & 5.47 & 6.60 & 9.40 & 11.33 & 182.57 & 96.47 & 30.67 & 0.51 \\
\hline $\operatorname{SEm} \pm$ & 1.17 & 1.41 & 1.30 & 1.31 & 0.090 & 0.209 & 0.195 & 0.259 & 2.393 & 3.125 & 1.439 & 0.005 \\
\hline $\mathrm{CD}(p=0.05)$ & NS & 4.19 & 3.86 & 3.90 & 0.270 & 0.621 & 0.582 & 0.770 & 7.109 & 9.287 & 4.275 & 0.016 \\
\hline
\end{tabular}


and at harvest stages. This provided better growth environment which recorded as better plant height as compared to other herbicide application and control. Perusal of data also reveal that different chemical weed control treatments evaluated in the present study were found to be vary significantly in their effect on number of leaves plant ${ }^{-1}$ in garlic. All the treatments significantly enhanced number of leaves plant ${ }^{-1}$ over control. Application of weed free treatment recorded maximum number of leaves $\left(8.10,10.83,12.80\right.$ plant $\left.^{-1}\right)$ followed by $(7.93,10.77$ and 12.67) with treatment Oxyfluorfen 23.5\% EC @ 1.01 ha $^{-1}$ at $60,90 \mathrm{DAS}$ and at harvest. The improvement results by this treatment in the growth parameter of crop seems to be on account of their direct impact on reduced weed density and periodical weed dry matter production as a result of which manifold reduction in crop weed competition occurred. Weed free environment also saved the growth inputs like moisture, nutrients, light and space and provided better edaphic and nutritional environment in the root zone, as a consequence, improved the growth parameter of garlic. The growth parameter (number of leaves plant ${ }^{-1}$ in Table 1) registered lowest in control (weedy) plots. Uncontrolled growth of weeds throughout the growing season of the crop in control (weedy) plots arrested the growth parameters due to severe crop weed competition. These finding are in close conformity with those of Vora and Mehta (1999); Naresh et al. (2006) who obtained the similar results in garlic and onion.

\subsection{Effect on yield and yield attributes of garlic}

It is evident from the results that all chemical weed control treatments evaluated in the present investigation significantly affected yield and yield attributing characters like neck thickness, no of cloves bulb ${ }^{-1}$, fresh and dry weight of 20 cloves, pollar and equatorial diameter of bulb, days to maturity, fresh and dry weight of bulb, bulb yield of garlic (Table 2). In all the weed management treatments, there were reduced crop weed competition thus saved a substantial amount of nutrients for crop that led to profuse growth enabling the crop to utilize more soil moisture and nutrients from deeper soil layers. Among the herbicide tested Oxyfluorfen 23.5\% EC (a) $1.01 \mathrm{ha}^{-1}$ recorded neck thickness $(7.87 \mathrm{~mm})$, no of cloves bulb $^{-1}$ (23.33), fresh and dry weight of 20 cloves (31.67 and $9.33 \mathrm{~g}$ ), pollar and equatorial diameter of bulb (35.42 and $42.43 \mathrm{~mm}$ ), days to maturity (131.33), fresh and dry weight

\begin{tabular}{|c|c|c|c|c|c|c|c|c|c|c|}
\hline Treatment & $\begin{array}{c}\text { Neck } \\
\text { thick- } \\
\text { ness } \\
(\mathrm{mm})\end{array}$ & $\begin{array}{c}\text { No. } \\
\text { of } \\
\text { cloves } \\
\text { bulb }^{-1}\end{array}$ & $\begin{array}{l}\text { Fresh } \\
\text { weight } \\
\text { of } 20 \\
\text { cloves } \\
\text { (g) }\end{array}$ & $\begin{array}{l}\text { Dry } \\
\text { weight } \\
\text { of } 20 \\
\text { cloves } \\
\text { (g) }\end{array}$ & $\begin{array}{l}\text { Pollar } \\
\text { dia- } \\
\text { meter } \\
\text { of bulb } \\
(\mathrm{mm})\end{array}$ & $\begin{array}{l}\text { Equa- } \\
\text { torial dia- } \\
\text { meter } \\
\text { of bulb } \\
\text { (mm) }\end{array}$ & $\begin{array}{l}\text { Days to } \\
\text { maturity }\end{array}$ & $\begin{array}{c}\text { Fresh } \\
\text { weight } \\
\text { of bulb } \\
\quad(\mathrm{g})\end{array}$ & $\begin{array}{c}\text { Dry } \\
\text { weight } \\
\text { of bulb } \\
\text { (g) }\end{array}$ & $\begin{array}{c}\text { Bulb } \\
\text { yield } \\
\left(\mathrm{q} \mathrm{ha}^{-1}\right)\end{array}$ \\
\hline Control & 3.99 & 12.33 & 20.50 & 4.50 & 29.21 & 32.18 & 140.67 & 19.47 & 5.83 & 52.86 \\
\hline Weed free & 7.91 & 24.00 & 31.83 & 9.50 & 35.72 & 42.92 & 131.67 & 30.70 & 11.33 & 126.63 \\
\hline $\begin{array}{l}\text { Pendimethalin 30\% } \\
\text { EC@ } 2.51 \mathrm{ha}^{-1}\end{array}$ & 5.28 & 18.00 & 24.00 & 6.50 & 33.54 & 39.22 & 137.33 & 26.53 & 9.23 & 96.40 \\
\hline $\begin{array}{l}\text { Pendimethalin 30\% } \\
\text { EC @ } 1.51 \mathrm{ha}^{-1}\end{array}$ & 5.24 & 17.33 & 23.33 & 6.17 & 32.32 & 37.72 & 140.00 & 25.83 & 8.83 & 78.21 \\
\hline $\begin{array}{l}\text { Oxyfluorfen } 23.5 \% \\
\text { EC @ } 1.01 \mathrm{ha}^{-1}\end{array}$ & 7.87 & 23.33 & 31.67 & 9.33 & 35.42 & 42.43 & 131.33 & 30.23 & 11.00 & 125.90 \\
\hline $\begin{array}{l}\text { Oxyfluorfen } 23.5 \% \\
\text { EC @ } 0.751 \mathrm{ha}^{-1}\end{array}$ & 7.13 & 20.67 & 24.67 & 6.50 & 34.45 & 40.10 & 134.33 & 28.07 & 9.17 & 86.54 \\
\hline $\begin{array}{l}\text { Oxadiargyl } 6 \% \text { EC } \\
\text { (a) } 1.01 \mathrm{ha}^{-1}\end{array}$ & 7.36 & 21.33 & 31.17 & 9.00 & 35.03 & 41.01 & 135.00 & 29.83 & 10.37 & 124.54 \\
\hline $\begin{array}{l}\text { Oxadiargyl 6\% EC } \\
\text { @ } 0.751 \mathrm{ha}^{-1}\end{array}$ & 7.17 & 20.67 & 29.00 & 8.17 & 33.65 & 39.88 & 133.33 & 28.10 & 9.67 & 100.07 \\
\hline $\begin{array}{l}\text { Oxadiazon } 25 \% \mathrm{EC} \\
\text { (@) } 1.01 \mathrm{ha}^{-1}\end{array}$ & 6.73 & 17.33 & 26.50 & 8.00 & 34.84 & 39.94 & 133.67 & 28.67 & 9.13 & 110.88 \\
\hline $\begin{array}{l}\text { Oxadiazon } 25 \% \mathrm{EC} \\
\text { @ } 0.81 \mathrm{ha}^{-1}\end{array}$ & 6.23 & 16.67 & 24.33 & 6.33 & 34.39 & 38.12 & 135.33 & 27.60 & 8.60 & 102.07 \\
\hline $\mathrm{SEm} \pm$ & 0.352 & 0.418 & 0.765 & 0.322 & 0.749 & 1.078 & 1.743 & 0.907 & 0.319 & 6.450 \\
\hline $\mathrm{CD}(p=0.05)$ & 1.048 & 1.244 & 2.273 & 0.958 & 2.226 & 3.205 & 5.179 & 2.695 & 0.950 & 19.221 \\
\hline
\end{tabular}


of bulb (30.23 and $11.00 \mathrm{~g}$ ), bulb yield (125.90 q ha-1). Thus under the present investigation, it was recorded that weed free followed by Oxyfluorfen 23.5\% EC @ $1.01 \mathrm{ha}^{-1}$ and Oxadiargyl 6\% EC@ 1.01 ha $^{-1}$ provided better yield and yield attributing character viz., neck thickness, no of cloves bulb ${ }^{-1}$, fresh and dry weight of 20 cloves, pollar and equatorial diameter of bulb, days to maturity, fresh and dry weight of bulb and bulb yield as compared to other herbicide tested because weed free improved the tilt by making the soil more vulnerable for the plants to utilize water and air, hand weeding provide aeration to deeper soil layers. These findings are in close agreement with other workers like Sandhu et al. (1997); Ankur et al. (2001); Adekpe et al. (2007), in garlic.

\subsection{Effect on quality of garlic}

The results revealed that there is significant effect of different weed control treatments on different quality attributes viz., leaf area plant ${ }^{-1}$, chlorophyll content (SPAD), T.S.S. content of bulb (\%) and volatile oil content of bulb (\%) in (Table 1). Leaf area plant ${ }^{-1}$ of garlic recorded at 120 DAS was significantly affected by different chemical weed control treatments. The maximum leaf area plant ${ }^{-1}\left(206.33 \mathrm{~cm}^{2}\right)$ was recorded at 120 DAS with the treatment Oxyfluorfen 23.5\% EC @ 1.01 ha $^{-1}$ applied as post emergence, followed by treatment weed free $\left(202.00 \mathrm{~cm}^{2}\right)$. The highest chlorophyll content (117.43 SPAD) of leaves was observed with the treatment weed free and it was at par with Oxyfluorfen 23.5\% EC @ 1.01 ha $^{-1}$ (116.75 SPAD) applied as post emergence and Oxadiargyl 6\% EC @ 1.01 ha $^{-1}$ (116.07 SPAD) applied as post emergence, respectively. The maximum T.S.S. content of bulb (35.67\%) was recorded with the treatment weed free and it was at par with Oxyfluorfen
23.5\% EC @ 1.01 ha $^{-1}(35.33 \%)$ applied as post emergence. The maximum volatile oil content of bulb $(0.63 \%)$ with the treatment weed free followed by treatment Oxyfluorfen 23.5\% EC@1.01 ha ${ }^{-1}(0.62 \%)$ applied as post emergence. The positive influence of the weed control levels on leaf area plant $^{-1}$, chlorophyll content (SPAD), T.S.S. content of bulb (\%) and volatile oil content of bulb (\%). Increased accumulation of nutrients especially in vegetative plant parts possibly with improved metabolism led to greater translocation ofthese nutrients to reproductive organs (bulb) of the crop. Similar experiments were conducted by Shanu et al. (2013) in coriander and Naruka and Dhaka (2001) in garlic crop

\subsection{Effect on weeds}

All the chemical weed control treatments applied in the presented study caused a significant reduction in weed population and weed dry matter (Table 3 ). In control (weedy), the weed population and weed dry matter increased tremendously due to uninterrupted weed germination and growth throughout the crop season. Simultaneous emergence and rapid growth of weeds led to severe crop weed competition for light, moisture, space and nutrients (Mani, 1977). The plots treatment weed free remained almost weed free up to harvest thereby providing congenial conditions for the growth of crop plants. At later stage of crop growth, weed cannot emerged possibly due to severe competition for moisture, nutrient, space, light, shadiness and short life of weeds. Similar results were obtained by Prasad and Singh (1988). Application of herbicides tried in the experiment led to significant reduction in dry matter production and weed population at all the stages of crop growth compared to control (weedy). Application of

Table 3: Effect of weed control measures on weed attributes of garlic

\begin{tabular}{|c|c|c|c|c|c|c|c|c|}
\hline \multirow[t]{3}{*}{ Treatment } & \multicolumn{4}{|c|}{ Weed population $\mathrm{m}^{-2}$} & \multicolumn{4}{|c|}{ Weed dry matter $\mathrm{q}_{\mathrm{ha}}{ }^{-1}$} \\
\hline & 30 & 60 & 90 & At & 30 & 60 & 90 & At \\
\hline & DAS & DAS & DAS & harvest & DAS & DAS & DAS & harves \\
\hline Control & 17.67 & 37.67 & 58.33 & 52.33 & 25.67 & 36.00 & 38.67 & 42.33 \\
\hline Weed free & 6.67 & 6.33 & 6.67 & 10.00 & 8.33 & 9.00 & 10.00 & 10.67 \\
\hline Pendimethalin 30\% EC @ 2.51 ha $^{-1}$ & 7.33 & 13.33 & 20.33 & 21.00 & 9.67 & 13.67 & 16.33 & 18.33 \\
\hline Pendimethalin 30\% EC @ 1.51 ha $^{-1}$ & 10.33 & 14.00 & 24.33 & 25.00 & 13.67 & 13.67 & 15.67 & 18.67 \\
\hline Oxyfluorfen 23.5\% EC @ 1.01 ha $^{-1}$ & 19.33 & 6.67 & 9.33 & 10.67 & 21.67 & 8.00 & 9.33 & 10.67 \\
\hline Oxyfluorfen 23.5\% EC @ 0.751 ha $^{-1}$ & 18.00 & 9.00 & 19.67 & 21.67 & 20.33 & 10.67 & 14.33 & 18.00 \\
\hline Oxadiargyl 6\% EC @ 1.01 ha $^{-1}$ & 19.33 & 7.00 & 9.33 & 10.00 & 21.00 & 9.00 & 11.00 & 11.67 \\
\hline Oxadiargyl6\% EC@0.75 1 ha-1 & 19.67 & 9.33 & 12.00 & 12.67 & 22.33 & 11.67 & 13.33 & 14.00 \\
\hline Oxadiazon 25\% EC @ 1.01 ha $^{-1}$ & 17.33 & 11.00 & 19.67 & 21.00 & 20.67 & 13.00 & 16.33 & 17.67 \\
\hline Oxadiazon 25\% EC@ @ 0.81 ha $^{-1}$ & 17.67 & 15.00 & 20.67 & 21.33 & 20.67 & 16.33 & 18.33 & 19.67 \\
\hline $\mathrm{SEm} \pm$ & 1.00 & 1.21 & 1.29 & 1.44 & 1.04 & 0.92 & 0.79 & 1.00 \\
\hline $\mathrm{CD}(p=0.05)$ & 2.97 & 3.60 & 3.83 & 4.27 & 3.10 & 2.73 & 2.36 & 2.98 \\
\hline
\end{tabular}


Oxyfluorfen 23.5\% EC @ 1.01 ha $^{-1}$ and Oxadiargyl 6\% EC (a) 1.01 ha $^{-1}$ treatments controlled the second flush of weeds that emerged at later stage of crop growth, this treatments registered $\left(8.00,9.33,10.67\right.$ and 9.00, 11.00, $11.67 \mathrm{q} \mathrm{ha}^{-1}$ weeds dry matter) at $60,90 \mathrm{DAS}$ and at harvest and weed population $\left(6.67,9.33,10.67\right.$ and $7.0,9.33,10.00$ weeds $\left.\mathrm{m}^{-2}\right)$ at 60,90 DAS and at harvest, respectively. These finding are close conformity with Vora and Mehta (1998) and Vora and Mehta (1999) in garlic. Oxyfluorfen is a contact herbicide and kills through the closing of stomata as result of increased membrane permeability and stimulate ethylene synthesis causing a loss of plastids from the bundle sheath and finally leaf abscission (Rao, 2000). Similar results were obtained by Shekar et al. (2002) in garlic.

\section{Conclusion}

The significant maximum growth, yield and quality attributes of garlic were recorded with weed free treatment followed by oxyfluorfen 23.5\% EC @ 1.01 ha $^{-1}$ and Oxadiargyl 6\% EC @ 1.01 ha $^{-1}$. Similarly minimum days to maturity, weed population $\mathrm{m}^{-2}$ at 60 and $90 \mathrm{DAS}$ and weed dry matter at harvest was recorded with weed free treatment followed by oxyfluorfen 23.5\% EC@1.01 ha ${ }^{-1}$ and Oxadiargyl6\% EC@1.01 ha ${ }^{-1}$.

\section{References}

A.O.A.C. 1970. Official and Tentative Methods of Analysis. 10 Ed., Washington, D.C.

Adekpe, D.l., Shebayan, J.A.Y., Chiezey, U.F., Biko, S., Tunku, P., 2007. Effect of weed control, date of planting and intra-row spacing on weeds and bulb yield of garlic (Allium sativum L.) at Kadawa, Nigeria. Advances in Horticultural Science 21(3), 165-171.

Ankur, V., Nandal, T.R., Singh, R.,Vermani, A., Singh, R., 2001. Nutrient uptake and economic weed management in garlic (Allium sativum L.) Indian Journal of Weed Science 33(3-4), 225-226.

Kilgori, M.J., Magaji, M.D., Yakubu, A.I., 2007. Effect of plant spacing and date of pla411nting on yield of two garlic (Allium sativum L.) cultivars in Sokoto, Nigeria. American-Eurasian Journal Agriculture and Environment
Science 2(2), 153-157.

Mani, V.S., 1977. Weed research in India, status problems and strategies. In: Proceedings of Weed Science Conference, Hyderabad 1, 27.

N.H.B., 2012. Indian Horticulture Database. National Horticulture Board, Govt. of India, Gurgaon, India.

Kumar, N., Mourya, I.B., 2006. Effect of different herbicides on growth and efficacy for weed control in onion (Allium cepa L.) seed crop. Annals of Agricultural Research 27(3), 245-249.

Naruka, I.S., Dhaka, R.S., 2001. Effect of row spacing and nitrogen fertilization on growth, yield and composition of bulb in garlic (Allium sativum L.) cultivars. Journal of Spices and Aromatic Crops, 10(2), 111-117.

Prasad, R.K., Singh, K.P., 1988. A note on the chemical weed control in onion. Haryana Journal of Horticultural Sciences 17 (3\&4), 282-284.

Rahman, U.H., Khattak, A.M., Sadiq, M., Ullah, K., Javeria, S., Ullah, I., 2012. Influence of different weed management practices on yield of garlic crop. Sarhad Journal Agriculture 28(2), 213-218.

Rao, V.S., 2000. Principles of Weed Science. Oxford and IBH Publishing Company Pvt. Ltd., New Delhi, 503.

Sandhu, K.S., Singh, D., Singh, J., Singh, D., Singh, J., 1997. Weed management in garlic (Allium sativum L.) under Punjab condition. Vegetable Science 24 (1), 7-9.

Shanu Naruka, I.S., Singh, P.P., Shaktawat, R.P.S., Verma, K.S., 2013. Effect of seed treatment and folior spray of thiourea on growth, yield and quality of coriander (Coriandrum sativum L.). International Journal of Seed Spices 3(1), 20-25.

Shekar, B.G., Ramachandra Prasad, T.V., Kenchaiah, K., 2002. Weed management in transplanted onion under protective irrigated situation. Indian Journal of Weed Science 34 (3-4), 327-228.

Vora, V.D., Mehta, D.R., 1998. Integrated weed management in garlic (Allium sativum L.) under Punjab conditions. Vegetables Science 24(1), 7-9.

Vora, V.D., Mehta, D.R., 1999. Studies on growth, yield and yield attributes of garlic as influenced by herbicides and weeds. Agricultural Science Digest, Karnal 19(2), 129-133. 